\title{
Ubuntu and the journey of listening to the Rwandan genocide story
}

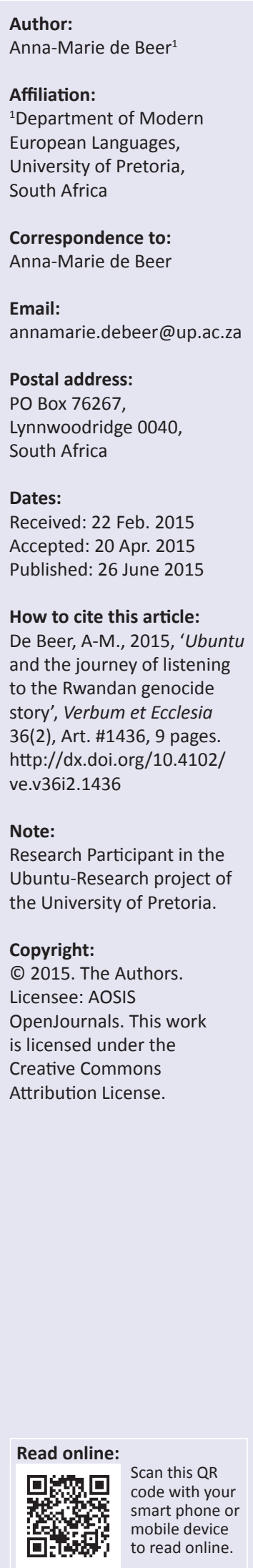

In the face of collective trauma such as genocide, apartheid, mass killings and xenophobia, ubuntu requires of us to show solidarity with our fellow human beings. To my mind, one of the highest forms of doing so is to open up spaces of authentic listening to the stories of those who have experienced these atrocities. In the genocide narratives of the commemorative project Rwanda: Écrire par devoir de mémoire (Rwanda: Writing as a duty to memory), travelling and writing become a mode of listening and transformation. However, this theme is articulated very differently in the many texts which form part of the project. This article concentrates on one such representation of the transformative voyage that the writers propose, namely the highly symbolic work of Koulsy Lamko.

We tell stories because in the last analysis human lives need and merit being narrated. (Ricœur 1990:75)

\section{Introduction}

Ubuntu is a capacious, multilayered and dynamic concept $t^{1}$ which is commonly accepted to be rooted in many African indigenous cultures. It has been interpreted as a worldview or a moral quality and depending on the context, it evokes notions of personhood, interconnectedness, communal harmony, 'universal human interdependence, solidarity and communalism' (Gade 2012:486). For the purpose of this article, I want to hone in on the concepts of solidarity, compassion and empathy which some consider to be a vital part of ubuntu: 'Its essence is about the capacity for empathy with another person' explains Pumla Goboda-Madikizela during an interview, 'that capacity to connect with another human being, to be touched, to be moved by another human being. That is $u b u n t u^{\prime}$ (cited in Gade 2012:489). It is this definition, proposed by Goboda-Madikizela, South-African researcher on postconflict reconciliation and traumatic memory, which leads me to consider the role of one who attempts to demonstrate ubuntu to those who have experienced the genocide of the Tutsis in Rwanda. It is precisely because this crime against humanity stems from the process of othering, that restoration can come about when another listens to their stories. In this article, I argue that for those who are not survivors or first person witnesses, a possible way of showing $u b u n t u$, or otherwise said, solidarity and empathy, is to listen to the narratives of those who did experience the genocide.

\section{Solidarity, compassion and empathy through listening}

Translating traumatic memory into narrative memory is a social process which involves an exchange between two persons that 'sets in motion the emergence of a narrative' (Bal in Bal, Crewe \& Spitser 1999:x). Both the victim and the listener are faced with a challenge: that of finding the words to transmit the impact of the event, and that of making sense of the often fragmented narratives offered by the victim. Laub views the activity of witnessing as a responsibility shared by the listener and the narrator:

Bearing witness to a trauma is, in fact, a process that includes the listener. For the testimonial process to take place, there needs to be a bonding, the intimate and total presence of an other - in the position of one who hears. Testimonies are not monologues; they cannot take place in solitude. (Felman \& Laub 1992:70-71)

Alexandre Dauge-Roth (2009) acknowledges the importance of this receptive stance by posing the question:

What does listening to a survivor entail and require? How does one envision, promote, and create a listening community for survivors? To what extent can we, as listeners, be implicated in and through the act of listening [...]? (p. 168) 
This question is partly answered by Laub, who has provided us with the term 'authentic listening' (in Caruth 1995:73) and who posits that the 'listening position' is one of being at the same time 'unobtrusive, nondirective, and yet imminently present, active' (in Felman \& Laub 1992:71). LaCapra offers us a description of a response that would be appropriate for a listener and which he terms 'empathetic unsettlement'. This would entail a way of listening that is attentive and empathetic without appropriating the voice of the victim (LaCapra 2001:98, 102-103). It refers to a measure of understanding and unsettlement which:

stylistically upsets the narrative voice and counteracts harmonizing narration or unqualified objectification, yet allows for a tense interplay between critical, necessarily objectifying reconstruction and affective response to the voices of victims. (LaCapra 2001:109)

From both these definitions provided for listening, it is clear that the person who listens is required to invest affectively in the process, whilst at the same time keeping an appropriate distance.

\section{Art and mediation of the story of trauma}

Bal (Bal et al. 1999:x) notes that art can 'mediate between the parties to the traumatising scene and between these and the reader' and the cultural nature of this process becomes evident when the 'second person who bears witness or facilitates self-witnessing is an artist or critical reader whose work functions as mediator'. Art, such as photographic images or literary representations of the event, can thus play a key mediating role in the process of witnessing, and Bal's observations underline both the importance of interaction in order for narrative integration to take place and the role that art can play in the process (Bal et al. 1999:x).

The activity of witnessing can indeed be taken one step further through art. This step involves allowing another to narrate one's story. Ricœur explains that narrative is 'a path to mourning' because mourning is a way of learning 'to narrate otherwise. To narrate otherwise what one has done, what one has suffered, what one has gained and what one has lost' (Ricœur \& Antohi 2005:23). ${ }^{2}$ The value of allowing the other to narrate one's story is underlined as follows:

One must know how to tell one's story as seen by others. That is to say, for me to let myself be narrated by the other. Not only for me to narrate myself otherwise (one can always do that, arrange and gather elements in another fashion), but to agree to let mimesis be produced by the other. That is difficult. (Ricœur \& Antohi 2005:24)

Ricœur's (1983) notion of triple mimesis describes this process in terms of configuration and refiguration of the story by such a 'mediator' or an other. In Ricœur's terms, making sense of an experience by narrating it is a process that takes place in the second phase of mimesis, which

2.1 am using the 2005 translated version of the original 2003 dialogue which is available at http://www.janushead.org/8-1/Ricoeur.pdf is the transition from prefiguration (the experience) to configuration (the story) and which ideally should lead to a refiguration of the story by the potential reader or listener. Various actors are required to participate in this process of storying; the victim who has lived the experience and tries to tell it, the writer or 'confirming witness' ${ }^{3}$ who listens to and attempts to configurate it, and the reader who listens or reads actively and participates in the process of refiguration. It is this interaction between victim, story, writer and reader or listener which is of interest to this article. Informed by the above theoretical tenets, let us now consider the interactive act of witnessing which re-establishes the communication interrupted by the trauma of genocide.

\section{Telling the story of genocide Writing and the duty to memory in Rwanda ${ }^{4}$}

The specific context that serves as example for this article is the transnational literary Fest'Africa project, ${ }^{5}$ which brought together writers from eight different African countries in 1998, four years after the genocide, in an attempt to respond to this event in their capacity as African intellectuals. These writers travelled together to Rwanda, where they spent a few months meeting the inhabitants of the country in trying to comprehend the origins and consequences of the genocide. ${ }^{6}$ This would be the first time in the history of African literature that writers from the continent would travel in a group to a country, so as to 'confront their thoughts and emotions together in order to produce works of fiction that were at the same time individual and collective' (Djedanoum 1999:1; translation $\left.{ }^{7}\right) .{ }^{8}$ Amongst the works that were published were a testimony and an essay by two Rwandans, as well as texts from a variety of literary genres by the non-Rwandan participants, ranging from travel narratives to novels and an anthology of poetry.

The very nature of the project, entitled Rwanda: Writing as a duty to memory, which required of a group of mostly nonRwandans to use their art to narrate a story they had not lived, places it within the category of what Ricœur calls agreeing to 'let mimesis be produced by the other' (Ricœur \& 3.i borrow this term from Bal (Bal et al. 1999:x).

4.For more information on this project as well as a detailed literary analysis of the nine texts which form part of the project, see my unpublished thesis in which I also discuss the notion of travelling as a form of listening and which has informed this article (De Beer 2013).

5.The writers who participated and eventually published texts as part of the project were Boubacar Boris Diop from Senegal, Tierno Monénembo from Guinea, Monique Ilboudo from Burkina Faso, Koulsy Lamko and Nocky Djedanoum from Chad, Véronique Tadjo from Côte d'Ivoire, Abdourahman A. Waberi from Djibouti, Jean-Marc Vianney Rurangwa and Vénuste Kayimahe from Rwanda. Meja Mwangi from Kenya was part of the original group but did not publish a text within the agreed timeframe.

6.Some of the writers who were not able to participate in the first visit travelled to Rwanda with a smaller group at a later stage. Others went back to Rwanda on their own, staying for various lengths. Koulsy Lamko, for example, returned to Rwanda after the project, in order to work at Butare's Centre for the Arts for an extended period of time (Kalisa 2006:517)

7.All translations from French are mine except for the citations from Véronique Tadjo's text which have been taken from the translation done in 2002 by Véronique Wakerley.

8.My translation is based on this citation: 'En effet, dans l'histoire de la littérature africaine, jamais un groupe d'écrivains ne s'étaient penchés sur le drame d'un pays africaine, jamais un groupe d'écrivains ne s'étaient penchés sur le drame d'un pays

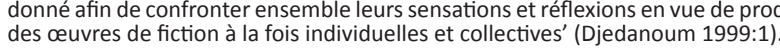


Antohi 2005:24). In this article, I pay particular attention to the texts by the non-Rwandans as I am interested in their role as potential listeners; the other who could show compassion to and solidarity with their fellow human beings, as suggested by the value system upheld by ubuntu. At the same time, as is remarked by Fonkua, many of these writers had experienced exile and other difficult situations in their birth countries and could in some way experience a sense of belonging or understanding of what had happened to the Rwandans (Fonkua 2003:70).

\section{Sharing the burden of memory}

Initiator of the project, Nocky Djedanoum, articulates the aim of the project by using terms which can be loosely summarised from the French as follows: acknowledging a responsibility towards the Rwandans which includes contributing to communal memory, acting as a voice for them, offering intellectual commitment, crying out in indignation, breaking the silence and thus bringing hope, visiting genocide sites, listening to and entering into dialogue with survivors and helping the Rwandans and the rest of Africa to understand that a global vision for the continent is needed. ${ }^{9}$ He states that the authors came to Rwanda to 'gather [their] thoughts, to listen, to observe, to try to understand and to reflect together' (Djedanoum 1999; translation). ${ }^{10}$ These words communicate notions of solidarity and kinship, listening and a commitment to sharing the burden of memory with those who experienced the genocide. ${ }^{11}$ Djedanoum (2000a:1; translation) expresses the doubt that their texts could actually ease the pain of the Rwandans but notes that he is convinced of the 'strength of the contact between them and the Rwandans, an encounter which requires the sharing of the mourning process' ${ }^{\prime}{ }^{12}$ Small $(2007: 87,88)$ acknowledges that transforming the desire to show solidarity through the project as proposed by Djedanoum, to a 'lived reality' is indeed a complex issue. At the same time she demonstrates how, in the face of erasure or silencing, the project attempts to insert the Rwandan genocide into history, thus signalling an act of irrevocable solidarity and a connectedness that $u b u n t u$ demands:

Djedanoum's solidarity is played out in the sense and in the hope of being more than a gesture but less than an invasive appropriation of the genocide as, for those who had not been involved, it would be impossible to identify with the experience of survivors in any way which could constitute a solidarity in that sense. But these texts, written in good faith, without the desire to

\footnotetext{
9.The phrases used by Djedanoum and on which i base my summary are as follows 'mémoire collective'; ' 'porte-voix'; 'engagement intellectuel'; 'notre ambition est de 'memoire collective'; porte-voix'; 'engagement intellectuel'; 'notre ambition est de
pousser encore plus fort et plus haut nos cris d'indignation. Des cris qui déchirent le silence et qui redonnent l'espoir'; 'd'avoir pris le temps de visiter les différents sites du génocide, d'avoir écouté les rescapés de tous âges et d'avoir discuté avec eux', 'faire comprendre aux Rwandais et au reste de l'Afrique que nous devons avoir une vision globale de ce continent' (Djedanoum 1999).

10.'[N]ous sommes venus nous recueillir, écouter, observer, essayer de comprendre et réfléchir ensemble' (Djedanoum 1999).

11.Geoffrey Hartman (2006:4) provides an insightful description on the role of the intellectual witness and the dangers of 'overidentifying' with the victim which has the potential of thwarting this role.

12.My translation is taken from the following phrases : 'Est-il acceptable de représenter la douleur des Rwandais quand on n'a pas éprouvé soi-même cette douleur? J'ai des doutes quant à soulager la douleur des Rwandais par nos écrits

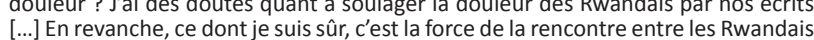
et nous, une rencontre qui impose le partage du deuil' (Djedanoum 2000a:1)
}

apportion blame or pass judgement, and without any trace of the conceit of being able to explain, may arguably create a space in which the perceived isolation of post-genocide Rwanda is broken. Through (the writing of) these texts, the genocide becomes part of Africa as a whole, part of the literature, history and actuality of African people, and inevitably not as a result or by extension, but simultaneously, part of humanity. (Small 2007:87, 88) ${ }^{13}$

One of the participants, Abdourahman Waberi (2004:16) expresses their task through a series of metaphors; the author is to erect a 'pantheon of ink and paper in memory of the victims' (panthéon d'encre et de papier à la mémoire des victimes) and to transform himself into a creator of echoes (se transformer en donneur d'échos). The writer becomes a 'melting pot receiving the victims' stories' (se faire creuset d'histoires et de récits de rescapés). These metaphors seem to imply 'receiving' and 'echoing' the story of trauma but at the same time configurating it according to Ricœur's process of mimesis; creatively selecting, ordering and narrating, and possibly adding one's own voice. Waberi (2004:17) hopes that what was destroyed by the power of the pen and propaganda may be healed by words as well as through listening and actively receiving ${ }^{14}$ the stories of Rwandans.

The sheer scale of this task explains why the writers offer us texts riddled with hesitation and self-reflexive comments on their incapacity to name the horror, to express not only the words, but also the silences of genocide: 'What else can one do? Hide oneself modestly. Listen attentively and mostly keep quiet [...] In short, what right do we have to speak?' (Waberi 2004:16; translation). ${ }^{15}$ Waberi acknowledges that we cannot really ever experience or express their pain and all that the writers could do for the victims was to 'listen to them at length, to brush against them lightly, to caress them with awkward words and silences' (2004:15; translation). ${ }^{16}$

Koulsy Lamko described his role as attempting to transform his own life as well as that of the reader through writing about the genocide. He likens himself to a 'passeur', a ferryman that moves between two shores, which reminds us of Bal's notion of mediation and the privileged but sensitive situation in which an intellectual finds himself when configuring the story of the other:

If I have a role to play [...], it is that of a ferryman. I should be able to be a medium through whom the words pass in order to be of use, to bring some change to [our] existence, both mine and that of others. ${ }^{17}$ (Lamko quoted in Kalisa 2005:263; translation)

13.Small's article (2007) provides an insightful discussion of the project as an attempt to demonstrate solidarity and the strategies used by the authors to do this, as well as the limits of this kind of endeavour.

14.I borrow the notion from Hartman (2006:8, my emphasis): 'Here the necessary function of intellectual, or secondary, witnessing is disclosed once more. It provides a witness for the witness, it actively receives words that reflect the darkness of the event'.

15.'Que faire encore? Se tapir modestement. Prêter l'oreille attentive et faire le plus souvent silence tout autour de soi. [...] Enfin, de quel droit prendrait-on la parole?' (Waberi 2004:16).

16.'[...] les écouter longuement, les effleurer, les caresser avec des mots maladroits et des silences' (Waberi 2004:15)

17.'Si j’ai un rôle à jouer [...], c'est celui de passeur. II faut que je puisse être le medium par lequel des mots passent pour pouvoir être utiles, pour changer quelque chos à l'existence, la mienne et celle des autres' (Lamko quoted in Kalisa 2005:263). 
The notion of the writer and his or her text acting as mediator complicates the process of traumatism-memorynarration due to the ethical implications of speaking on behalf of another, and at the same time, it opens up new possibilities. It is this potential of the project that is the focus of my deliberations.

\section{Invitation to a collective journey}

These authors journeyed to Rwanda and, confronted with genocide, they found themselves changed..$^{18}$ Borrowing from Tadjo's metaphor of the travel diary, in L'ombre d'Imana: Voyages jusqu'au bout du Rwanda, translated by Véronique Wakerley in 2002 as The shadow of Imana: Travels in the heart of Rwanda, I will attempt to trace the journey undertaken by the participants of the project in addressing the challenges of narrating the other's story. Germanotta (2010:11) notes that due to the testimonial element present in the project, the journey takes on an aspect of an initiation quest: the traveller coming from elsewhere seeks to obtain knowledge and understanding from those who have experienced the genocide, and thus travels to the sites which contain the memories of this event.

In my analysis of the nine texts of the project, it has become clear that what would be expected of those who embarked on this journey, was to go, as Tadjo's (2000) subtitle so aptly suggests, 'jusqu'au bout du Rwanda'19. Implicit to this process is a willingness to listen, to re-examine oneself and be transformed on various levels by the voyage. Fonkua (2003:71) points out that travelling is a recurrent theme in the books from the project. Nayar (2009:430) observes that travel writing is 'a genre that enables the empathetic listener and observer [...] to record her/his encounter with the Other'. Nayar (2009:35, 36), who focusses his analysis on Tadjo's text, has described it as a form of 'affective travel' which offers us travel literature based on an individual's journey through 'genocidal space'. He (Nayar 2009:38, 46) suggests that her text is a mix of the observation mode, which provides factual information about the country, and the 'deeply subjective, affective mode' which focusses on the pain of the individual and elicits an 'affective' response from the reader.

Allowing oneself to be thus transformed and unsettled by the narrative is to my mind the ultimate form of authentic listening. I would therefore like to explore how this progressive process is presented to the reader through the motif of travelling as mode of listening and of transformation. Koulsy Lamko, Véronique Tadjo, Boris Diop, Abdourahman Waberi, Monique Ilboudo and Nocky Djedanoum all craft

18.Audrey Small notes that Djedanoum "made it a condition of their participation that each of the writers make themselves available to go to Rwanda for a period of two months; discussing the project after its completion, the writers involved agreed that the experience of going to Rwanda, speaking to survivors and seeing what that the experience of going to Rwanda, speaking to survivors and seeing what
are now called the 'sites' of the genocide fundamentally changed their idea of their task. Some also felt that what they had seen and heard had fundamentally (Small 2007:86).

19.This implies the notion of seeing something through to the very end, or as translated by Véronique Wakerley, to travel into 'the heart' of Rwanda. their texts around this trope by mapping out the journey of a character or writer who becomes initiated into the horror of genocide. ${ }^{20}$

The 'traveller' from the texts of the project (I use this term for both its literal and symbolic connotations of being in limbo, in between worlds, languages and cultures, open to new experiences) is an outsider on various levels - nonRwandan or exiled Rwandan, absent or intellectual witness, uninitiated into the historiography, myths and customs of the country. With time, knowledge of the country and the genocide is acquired, first on a cerebral level based on facts and figures. This awareness gradually becomes more physical and intimate, portrayed in the texts through the evocation of shocking visual images and smells associated with the genocides sites, disturbing encounters with victims and perpetrators, and violent reactions of the visitor to these experiences.

The writers, like their characters, have to learn to navigate between their first impressions and that which is concealed behind the masks offered by the country, its people and its landscapes. This art will be a part of their voyage of initiation and will allow them to go jusqu'au bout du Rwanda in order to travel beyond mere tourism. Thus, superficial knowledge transforms itself into profound discomfort prompted by contact with the inhabitants (dead and living) of the country and the realisation of the burdens of memory they carry.

The transformation undergone by the traveller entails a loss - being stripped of luggage, of photos taken, of points of reference; thereby symbolising the ceding of assumptions, ignorance and facile acquisition of knowledge of the genocide. It requires an awareness and acknowledgement of one's own involvement, one's own relation to the genocide, like Cornelius, Diop's exiled character who returns to his country to write a book about the genocide, only to discover his father's nefarious role during this event, Tadjo, the writer who recognises her own country, Côte d'Ivoire, in the streets of Rwanda, Pelouse, Lamko's protagonist who starts to sense the profound roots that tie her to the country from which she has been exiled, and Venant, a 'hero' of the genocide in Ilboudo's text, for whom the burden of the knowledge of man's inhumanity reduces him to becoming a perpetrator in his own household after the genocide. In my analysis, I will place the emphasis on the journey of one such travelling listener, as portrayed in the work of Koulsy Lamko. $^{21}$

20.This process is embodied in various forms in the texts written by Tadjo, Lamko Waberi, Diop and Djedanoum. In Ilboudo's text, it can be applied to the character of Venant, but in his case, the process unfolds in a different way, and his initiation into the horror of genocide results not in a deeper understanding, but in destruction and a psychological breakdown.

21.Whilst working at the Butare centre for arts after the project, 'Lamko experimented with various stage forms, particularly with Augusto Boal's Theatre Forum where participants could provide input to the process of reconstruction. In addition to participants could provide input to the process of reconstruction. In addition to arranging several worts, Lamko con conflict resolution, AIDS, women's rights and other social issues in post-genocide Rwanda. Lamko has staged conflicting views on what happened in 1994 and on what should happen after the genocide. In performances that lasted hours, he allowed the audience, mostly students, to intervene in case they disagreed or wanted to add to the debate' (Kalisa 2006:518). 


\section{Lamko: From the real to the symbolic}

Although Koulsy Lamko (2002:1) himself is hesitant to ascribe a certain genre to his text entitled La Phalène des collines (The Butterfly of the hills), literary critic, Eloïse Brézault (2000:1), calls it an allegorical tale. Lamko's text is indeed a symbolic evocation of the genocide. Travel becomes a metaphor for listening and the journey(s) of transformation evoked by Lamko does not centre around the experience of the foreign writer or visitor only. It is woven around the stories of three main characters who represent different voices and different modes of travelling.

\section{The butterfly}

The story of la Phalène or the Butterfly is that of a Tutsi queen, raped and murdered by a priest in a church during the genocide. After her death, she is incarnated in the form of a butterfly, roaming around angrily and waiting for someone to take pity on her soul and bury her according to the customs, so that she can cross over to the 'Hills of the Dead' (La Colline des Morts) (2002:56). This quest is ultimately her journey. Through her meticulous descriptions of her surroundings, akin to a lens that has zoomed in to the world, this mythical character provides a unique view of the world, a subtle reminder by the author of the variety of points of view and multiple truths that exist about any historical event.

Lamko characterises the Butterfly with the action of moving effortlessly between the spiritual and physical realm: 'I fly away' (Je m'envole), 'I soar' (je m'élève) (Lamko 2002:13, 14). It is indeed the person of the Butterfly who most vividly brings us back to some of what has been described by Mphahlele (2003a:284) as 'traditional values' inherent to 'African humanism', or otherwise known as ubuntu, namely 'respect for the elders, sense of community, neighbourly attachments, sense of ancestral presence, the appropriate funeral rites, solid social relationships'. The author's choice of using as omniscient narrator a protagonist who seamlessly moves between the visible and invisible world, demonstrates his awareness of what Véronique Tadjo (2013:2) has described the 'belief in the existence of a hidden world interpenetrating our living one' and what she claims to be the 'common essence of most African religious systems'. Tadjo (2013:2) furthermore evokes that 'bridge between life and death thanks to which the two remain connected', noting that those who "live in the "visible" world have the duty to keep the communication open and to nurture the "invisible" world [...]'. Tadjo (2013:2) reminds us that according to this belief system, 'the dead keep living, going about their business and interfering in real life'. This aspect is demonstrated in both Tadjo and Lamko's texts; Tadjo $(2013: 3,4)$ dedicates a whole chapter of her travel account to writing a tale that makes the reader aware of the 'Wrath of the Dead' roaming around the streets of postgenocide Kigali and Lamko bases his novel on the narrative of the Tutsi queen metamorphosed into a Butterfly. What these two approaches have in common, apart from engaging with the presence of the dead, is their insistence on performing the correct burial rites according to Rwandan custom, in order to allow the dead to be at peace. ${ }^{22}$

The character of the Phalène (Butterfly) is inspired by Mukandori/Mukandoli, ${ }^{23}$ a Tutsi girl cruelly bound and raped during the genocide and whose body had been displayed at the genocide site of Nyamata church and viewed by the authors during their visit to Rwanda. Visibly shocked by the cruelty of her death, they insert this victim into their texts in various ways. Lamko makes of her an allegorical, supernatural figure. At the moment of being raped she leaves her 'shell' and crosses 'the border between being and nothingness, to this unlimited territory where one participates immediately in the nonvisible realities' (Lamko 2002:46; translation). ${ }^{24}$ Eventually, she metamorphoses herself into a butterfly: 'Simple process of metamorphosis to move from the invisible to the visible, from the aphysical body to the incarnated (Simple opération de métamorphose pour passer de l'invisible au visible, du corps aphysique à l'incarné) (Lamko 2002:28-29).

This beautiful red Butterfly is at the same time frivolous and vulgar. The paradoxes related to her repel, alienate and disorientate the reader, stripping us of conventional ways of analysing her. Perhaps the unrefined tone of this fragile insect, who traditionally evokes connotations of beauty and elegance is meant to transmit the unexpected brutality of the genocide and its effect on those who witnessed it. It is only gradually that the reader's discomfort is transformed into comprehension, guided also by the introduction in the text which sheds light on Lamko's narrative strategy. $\mathrm{He}$ explains that the poet's work is not to simply enumerate, but to bring to life the statistics, an action which is not clear and simple. He does this by creating, a polyphonic work of painful cacophonic arpeggios ('une polyphonie sur des arpèges de cacophonies douloureuses'), which aims not to soothe the reader but to reflect the horror and the pain, at the risk of unsettling the reader (Lamko 2002:12).

\section{Fred $R$. and living in exile}

Fred R., ${ }^{25}$ the second main character, is the eternal traveller, the exiled Rwandan, a stranger who does not even have a surname and who is constantly in search of his homeland.

\footnotetext{
22.For a detailed discussion on how Tadjo's text deals with the issue of burial rites and the presence of the dead in Rwanda, read my forthcoming publication and the presence of the dead in Rwanda, read my forthcoming publication 'Ubuntu, reconciliotion in Rwanda and returning to personhood through collective exion of interconnectedness, as it exists in ubuntu ethics. This publication considers how this invisible link between humans, the dead and the living, man and the cosmos informs Tadjo's text. It looks at interconnectedness in the following three ways: the aspects of her text which confirm our shared humanity, as well as the tale which she tells about the dead who roam around Kigali haunting the living because customary burial rites have been sidestepped. Finally, I consider her portrayal of man's inhumanity to man and which demotes him to the realm of the animal, serving as the ultimate example of a 'break' in interconnectedness and humaneness.
}

23. Both versions of her name are used by the authors from the project.

24.'Me voici partie! Hors de ma coquille. Je passe la frontière entre l'être et le néant pour ce territoire de l'illimité où l'on participe immédiatement à des réalités non visibles' (Lamko 2002:46).

25. His name brings to mind General Fred Rwigema, cofounder of the Front patriotique rwandais with Paul Kagame, and who died in 1990. 
Lamko (2002:20) associates him with the motif of running and it is his perpetual, restless roaming that in turn links him to the Butterfly, whose life, Lamko writes, is nothing other than a perpetual migration, filled with uncertainties and metamorphoses.

\section{Pelouse and the journey of listening}

The third journey is of specific interest because of the parallels that can be drawn between it and the journey of listening undertaken by the writers of the project. It is that of the Butterfly's niece, Pelouse who is searching for her aunt's tomb. Pelouse is characterised by her huge (monstrueux) Canon camera that she carries around everywhere (Lamko 2002:24). She has Rwandan roots but grew up in exile in Paris, visiting the country for the first time after the genocide, together with a delegation of French visitors. She acts as tourist, guide, interpreter, 'script-girl' and photographer for them.

Her role is to take notes and photos of the genocide sites that they visit, a task that she initially approaches like someone taking an inventory. She undertakes various visits to the genocide sites with the delegation and is expected to 'grip the camera lens in order to fix and express the nausea, the absurd, the inexpressible, the violence and all this with that authenticity that can only be arrived at through the truth of a double gaze' (saisir l'objectif de l'appareil pour fixer et dire la nausée, l'absurde, l'ineffable, la violence et cela avec cette authenticité qui seule apporte la vérité d'cil double) (Lamko 2002:140). Her notes are to become the 'backbone' (l'épine dorsale) of the delegation's report on the genocide (Lamko 2002:140).

Like the writers from the project, she is the stranger who arrives from elsewhere and after the fact, attempting to capture the reality of the genocide 'vicariously' (par procuration), through the lens of her camera and fastidious note-taking (Lamko 2002:25). This preoccupation with sensationalism and virtual images through lenses and screens fills the Butterfly with disdain and she calls it 'unconfessed cannibalism' (Cannibalisme non-avoué!), suggesting that the bodies of those that are photographed are 'eaten' by the photographer who seeks to satisfy some kind of emotional appetite (Lamko 2002:24-25).

When Pelouse visits the genocide site where the murder of her aunt took place (although she does not yet know that the story told to her by the guide is that of her aunt's), she attempts to take some photos of the body of the raped woman but the Butterfly intervenes and scares her. Disillusioned by the inappropriate way in which the guide narrates her story to visitors, and tired of waiting in vain for someone to take pity on her and bury her in an appropriate way, the Butterfly leaves the church and follows her niece.

Ironically therefore, when Pelouse crosses paths with her in the form of a butterfly, she does not recognise her and flees her presence because of her fear of butterflies to which she declares herself to be allergic. This too is symbolic - as the reader will discover, she cannot recognise her aunt because she has not yet become sensitive to the spiritual world into which her contact with her aunt and her experience of Rwanda will gradually initiate her. Furthermore, the author obliquely reminds us that the outsider witness, attempting to understand the genocide, risks being unsettled and disorientated by the reality of the genocide which takes on unexpected forms. Her journey becomes a voyage of discovery, questioning and introspection.

Lamko's acknowledgement of his role as listener, and passeur (ferryman or boatman) evokes interesting connotations when read in conjunction with his text and its allusions to the Butterfly's desire to be allowed to cross over to the other world, as well as Pelouse's desire to understand the genocide. Within the context of the notion of travelling and transformation, one can deduce that Lamko's desire expressed here is to take the reader with him from a position of possible ignorance or disinterest to 'the other side', where he 'knows' and is changed by that knowledge. Parallels can be drawn between Pelouse (script-girl, photographer and interpreter), and Lamko, author and 'passeur'. Both are belated witnesses to the genocide which they attempt to represent. Both set off on a journey of discovery and act as mediator or go-between; she between Rwanda and the French visitors, although she does not know the country herself and he between the event and the reader, although he did not experience the genocide.

\section{Opening her eyes to the invisible}

Pelouse's first symbolic choice which will set her apart from her fellow travellers is to stay in a small hotel in a poor area in Kigali, rather than the infamous and now touristy Hôtel Mille Collines. They reproach her for separating from the group and wanting to 'immerse' herself in the 'swarming, foul-smelling mob' (la grouillante et puante populace) represented by the local population, but they will remain mere tourists, whilst she undergoes her journey of unsettlement (Lamko 2002:94).

The restaurant in the small hotel where she stays is the gathering place for those who have been wounded by the genocide and they meet here to 'get drunk and forget' (s'enivrer et oublier) (Lamko 2002:66). Here she meets two survivors who are caught up in the recurring circle of trauma and will accompany her on her journey of listening: Muyango-le-crâne-fêlé (Muyango-the-cracked-skull) who writes and rewrites his poetry and Épiphanie, who suffers from insomnia and drinks in order to survive the memory of having witnessed the cruel murder of her husband and children at the hand of her own cousins.

Pelouse discovers that some of the photos that she took in the church, are blank - although she took great care to develop them correctly. The reader learns that it is in fact the work of the Butterfly who refuses to be caught up in 'a black box' (Lamko 2002:111). Both her aunt, the Butterfly who visits her hotel room, and Muyango who becomes her friend, encourage her to discover her potential instead of limiting herself to the duty that is expected of her, and this time, she does not flee 
from the Butterfly (Lamko 2002:88-89). The Butterfly decides to arm her niece with a 'double vision' (d'une double vue) and a 'double ear' (une double écoute) so as to sensitise her to the invisible realm and thus enable her to better understand the Rwandan history and context (Lamko 2002:102). She explains to Pelouse the process that she will need to undergo:

If you really are looking for me, if you are looking for my tomb, if you want to be freed from all fears, you will need to learn to understand the hidden things of life, those which exist beyond the physical world. Do not fear obstacles. The boundary only exists in the minds of those who confine life to watertight compartments. (Lamko 2002:144; translation) ${ }^{26}$

The Butterfly's decision to help her niece see in a different way is reminiscent of Tadjo's (2013:2) remarks on one of her novels The Blind Kingdom which the author claims is 'a multilayered narrative' in which 'oral and religious traditions occupy an important place'. Tadjo (2013:2) explains that the story is 'about an African society on the brink of collapse' during which Akissi, 'the blind daughter of the King, goes through an initiation that will help her to metaphorically "open her eyes" and embrace the complexity of life'. The process of initiation that Pelouse undergoes in Lamko's novel will earn her the right to represent the story of the murdered queen and her people, just like an outside narrator will need to be transformed before being able to narrate the story of the Rwandans.

As with Tadjo's journey, Pelouse will experience a loss and a period of disorientation. Tadjo situates the start of her physical journey in South Africa and provides a detailed description of the detour required in order to arrive at Kigali. The evocation of this detour contributes to an atmosphere of incertitude and tension as the narrator gradually becomes more disorientated. The airport is crowded; she has to run not to miss her connecting flight and in the process loses her luggage. When she writes, 'I have difficulty in getting my bearings' (Tadjo 2002:6), the reader senses that her discomfort is deeper than a physical disorientation and loss. It seemingly involves being stripped of that which is familiar to her, suggesting that she is about to leave behind her comfort zone, her 'bags' filled with already acquired tools of her trade for the process of writing, as well as her prejudices and assumptions.

In Pelouse's case, the loss will not be her luggage, but all her notes that she has meticulously kept about her visits to various places in the country. Her notes are destroyed and she loses her camera bag with her rolls of film during a mysterious and violent storm that lasts more than twenty hours and of which the writer suggests that the origin is supernatural. She will be forced to revisit her attempt of making an 'inventory' of the genocide, in order to include the human dimension, as is suggested to her by Muyango, the survivor who urges her to transform her inventory into a 'hymn' to her 'beloved'

26. 'Si tu me cherches vraiment si tu cherches ma tombe si tu veux être affranchie de toutes les hantises, il faut que tu apprennes à saisir les choses cachées de la vie, celles grouillantes au-dela du sensible. Naie pas peur des obstacles. La frontière n'existe que dans l'esprit de ceux qui bornent la vie en compartiments étanches' (Lamko 2002:144). country (Lamko 2002:113,161). This human dimension comes to her through her intimate contact with the Rwandans and a growing awareness of the consequences of the genocide in their individual lives as well as her growing consciousness of the hidden, spiritual realm. Pelouse, like the authors from the project, is required to learn to listen and to see differently before attempting to even think of 'sharing' the pain of the Rwandans.

She is forced to interrupt her quest of searching for her aunt's tomb, in order to listen to the painful story of Épiphanie, the survivor who suffers from insomnia and who has crossed her path. Épiphanie's life is described by Lamko as a philosophy of survival (philosophie de survie) (Lamko 2002:69), during which she drinks to forget her genocide experiences and the murder with a pruning knife of her husband and children. She alone witnessed this cruel act and jealously guarded this horrible secret to herself (Lamko 2002:68). Her philosophy is in fact a vicious circle typical of those caught up in trauma that has not been verbalised and reminds us of the need for survivors to configure and verbalise trauma in order to escape from such a circle.

It is only when she tells her story to Pelouse, who listens attentively to her, that she escapes from it and for the first time in five years manages to sleep well. Pelouse is no older than Épiphanie but the process of listening and thus accompanying her on her road of mourning, will transform her into a maternal figure, whom Épiphanie calls 'Little mother' (Petite mère) (Lamko 2002:172). It is through this relationship between Pelouse and the young widow, Germanotta notes, that the writer 'expresses the hope' (exprime l'espoir) that the sympathetic ear of an outsider can facilitate the work of mourning (Germanotta 2010:21-25).

The transformation undergone by Pelouse is a process which will bring her to the point of acknowledging her Rwandan roots, thus renouncing her 'external position' (position extérieure), which is 'detached' (détachée) from other Rwandans, in order to 'take on their pain' (se charger de leur douleur) (Germanotta 2010:14). Indeed, in the case of Pelouse, not only does travelling become a mode of listening, but listening becomes a form of travelling, of displacing oneself into the journey that the other has made. It is also Pelouse, who will eventually perform the burial rites for her aunt, becoming in turn a 'passeur' that will allow the Butterfly to leave on her final journey towards the 'City of Time': 'I float towards the City of Time. In the crossing, on the great river, in a pirogue, I am jubilant. All around me, the birds chirp freedom' (Je vogue vers la Citédu Temps. Dans la traversée, sur le grand fleuve, en pirogue, je jubile. Tout autour de moi, les oiseaux pépient liberté) (Lamko 2002:216).

Lamko's choice of narrator reveals in various ways his desire to tell the story in a way which endows it with the traditional values that Mphahlele (2003a:284) links to African humanism. The Butterfly's mere incarnated state of being points to border-crossing and the awareness of ancestral presence. Furthermore, her restless wandering which is born 
from the lack of closure due to the violation of bural rites shows the importance of customary rites in establishing harmony between those who have died and those who are left behind. The relationship that develops between her and Pelouse demonstrates the sense of respect for elders and the importance of relationships. Her insistance on opening Pelouses's eyes to the hidden world, the spiritual realm, further confirms this stance by pointing to the connectedness with the higher spiritual realm and the integral role played by the spiritual and religious in traditional African humanism (Mphahlele 2003c:151).

Not only the Butterfly, but also the author's choice of genre demonstrates his desire to tell the story of genocide in a way which would resonate with those are familiar with these traditional values. Mphahlele (2003b:135) has upheld the myth as a form of narrative which enriches us, due to its 'compelling poetry' its allegory and its 'symbolism', showing how the myth is a vehicle which 'promotes harmony between humans and nature in a triumphant, inviolable, pantheistic union that negates death'. It is precisely this quality of Lamko's writing, his use of allegory and the symbolic, his focus on ritual and his voluntary journey into a place where boundaries between death and life, between the survivors and the dead, between myth and reality, between the natural and the supernatural collapse, that in my view positions him as an authentic listener and narrator of the story of those who embrace this worldview.

Given Mphahlele's (2003b:139) statement that 'poetry is a way of perceiving, a way of seeking to touch the Highest Reality beneath the surface of things', it is significant that Muyango-the-cracked-skull, traumatised by the genocide, is also Muyango the poet. He is the one who urges Pelouse to open her eyes to the hidden world, and enhance her writing and her photos with new 'rythms' and 'emotions' which will 'celebrate' a new form of humanity to be 'engendered' by the lakes, the hills and the flight of the weavers that she sees around her (Lamko 2002:113). This admonishment is reminiscent of Mphahlele's (2003b:135) evocation of the 'harmony between humans and nature' provoked in a 'triumphant, inviolable, pantheistic union that negates death'. It is Muyango who will assist Pelouse in performing the burial rites so that her aunt can find peace. Muyango is also the survivor who finds healing in working through the process of mourning, and telling his story to Pelouse. We learn that he too was unable to bury his family who died during the genocide and has been walking around covered in the blood and fat taken from their corpses (Lamko 2002:124), and refusing to cut his nails or his hair. However, when Pelouse and Épiphanie open a salon, surrounded by flowers, which they call the 'Clinic of Hope' (La Clinique de $l^{\prime}$ Espoir) and in which they hope to cut off not only the hair that women grew for mourning, but also the 'despair' that burdened their souls, Muyango arrives with a pair of scissors and a razor, asking them to cut off his hair of mourning and his nails which have become like 'claws' (p. 198). ${ }^{27}$

27.1 would like to acknowledge the contribution of the reviewer here, who urged $\mathrm{m}$ to explore in more depth the notions of collapsing of boundaries and of bordercrossing, both within the concept of ubuntu and within Lamko's text.

\section{The genocide sites and empathetic unsettlement}

When Pelouse visits Bisesero, the narration of the events that took place there and the atmosphere of the site profoundly move her. She has the impression of having lived through the events herself. She stops taking photos, feels ill and faints. Of the group of visiting strangers, she appears to be the only one who is so strongly affected by what the victims have experienced. This reaction is significant because it seems to point to the conditions necessary for an outsider to be in a position to narrate the trauma lived by others. It is akin to what Dominick LaCapra (2001:102-103) has called 'empathetic unsettlement' and is experienced in the project by those who undertake a pilgrimage to the genocide sites, 'an ordeal' that one will never get through without this 'inner upheaval' or unsettlement, and likened by Pierre Halen (2005:190) to a 'type of initiation'. ${ }^{28}$ Unsettlement takes on various forms such as the dizziness and distress felt by Pelouse, anger and a sense of disorientation as shown by Diop's main character Cornelius, or a complete psychological breakdown as is experienced by Monique Ilboudo's characters. In Tadjo and Waberi's travel diaries, the unsettlement comes in the guise of self-doubt, self-interrogation and feelings of inadequacy to completing the task, as experienced by the authors.

\section{Conclusion}

\section{Continuing the journey of memory}

The genocide sites become a physical presence in the texts of the project, provoking visceral reactions in those who visit them. For Rwandans, these ambiguous places are sites of conflict between forgetting and commemoration, private and public imperatives, progress and duty to memory. For the visitors, trying to move beyond first impressions, stereotypes and a superficial understanding of the genocide, these sites are places of unsettlement, self-interrogation and transformation. The authors, locating many of their reflections at these evocative sites, offer no solution, only point out the complexity of the paradox and the effect it has on the society. It is also the contact with these sites that invite, more than anything else in the texts, the reader to listen to and refigure the story so as not to remain unmoved. ${ }^{29}$ By sharing their horror, their discomfort and disorientation, the authors implicitly encourage us to be transformed by what we read.

If it is true then, that ubuntu symbolises harmony and connectedness with the other, the cosmos and the Supreme Being, as well as humaneness towards our fellow human beings, it stands to reason that genocide, apartheid and xenophobia are extreme violations of the spirit of ubuntu. Healing would then by definition involve some form of recovery of the harmony and connectedness, shattered by the

28.Pierre Halen (2005:190) describes this phenomen as "une épreuve dont on ne saurait venir à bout sans ce bouleversement intérieur qui est une manière $d^{\prime}$ initiation' and it is from this citation that I translate here.

29.At the same time, Norridge (2009:144) cautions us against the danger, pointed out by Susan Sontag, of allowing our feelings of sympathy, our 'emotional identification' and 'narratives of pity' to absolve us from responsibility and action. 
violence and maybe this is precisely how indigeneous value systems such as ubuntu with its awareness of solidarity, empathy, and the hidden spiritual connections, can provide us pathways to healing and restoration, a way of returning to our personhood.

The journey requires of us too to be initiated into that which is hidden, to look, as Tadjo (2002:11) suggests under the skin and into the eyes of the Rwandan people. We are free to react as we can - with anger, disgust, and a sense of powerlessness or disillusionment. Yet, we cannot emerge from this journey untouched and unmoved.

Thus, the project becomes a pilgrimage, embarked on by the authors, and shared by the reader. We are reminded that memory is a two-edged sword, and that it is too heavy a burden to carry, especially when carried on one's own. This is why the authors offer to 'receive the words' (Hartman 2006:8) that reflect the pain and the mourning of the Rwandan people. It is also why they show us that the dead as well as the living need to be heard, and that listening to their stories, and being profoundly disturbed by them, allowing ourselves to be touched, moved and transformed by their pain is something that $u b u n t u$ requires of us and that we can do for them.

\section{Acknowledgements Competing interests}

The author declares that she has no financial or personal relationships which may have inappropriately influenced her in writing this article.

\section{References}

Bal, M., Crewe, J.V. \& Spitser, L., 1999, Acts of memory: Cultural recall in the present, University Press of New England, Hanover.

Brézault, E., 2000, La phalène des collines, de Koulsy Lamko, viewed 17 November 2012, from http://www.africultures.com/vitrine/rwanda/rwanda.htm

Caruth, C., 1995, Trauma: Explorations in memory, John Hopkins University Press, Baltimore, MD.

Dauge-Roth, A., 2009, 'Testimonial encounter: Esther Mujawayo's dialogic art of witnessing', French Cultural Studies 20(2), 165-180. http://dx.doi. org/10.1177/0957155809102632

De Beer, A.-M., 2013, Le voyage de l'écrivain vers une voix, une histoire et un futurune étude du projet littéraire, Rwanda: Écrire par devoir de mémoire, Unpublished thesis, University of Johannesburg, Johannesburg.

Diop, B.B., 2000, Murambi: Le livre des ossements, Stock, Paris.

Djedanoum, N., 1999, Le Rwanda, terre de recueillement de mémoire, viewed 01 November 2011, from http://nocky.fr/ecrits-inedits/

Djedanoum, N., 2000a, Discours d'ouverture de Nocky Djedanoum à l'ouverture du colloque international - Fest'Africa sur le génocide des Tutsi et le massacre des Hutu modérés, viewed 01 November 2011, from http://nocky.fr/ecrits-inedits/
Djedanoum, N., 2000b, Nyamirambo!, Le Figuier/ Éditions de Fest'Africa, Bamako, Lille.

Felman, S. \& Laub, D., 1992, Testimony: Crises of witnessing in literature, psychoanalysis, and history, Routledge, New York.

Fonkua, R., 2003, 'A propos de l'initiative du Fest'Africa: "Témoignage du dedans", "témoignage du dehors"', Lendemains 28(112), 62-72.

Gade, C.B.N., 2012, 'What is Ubuntu? Different interpretations among South Africans of African descent', South African Journal of Philosophy 31(3), 484-503. http:// dx.doi.org/10.1080/02580136.2012.10751789

Germanotta, M.A., 2010, 'L'écriture de l'inaudible: Les narrations littéraires du génocide au Rwanda', Interfrancophonies - Mélanges, 1-34.

Halen, P., 2005, 'Le Rwanda et la question de l'altérité: À propos de deux récits de voyage', in R.B. Gallimore \& C. Kalisa (eds.), Dix ans après: Réflexions sur le génocide rwandais, pp. 189-208, L’Harmattan, Paris.

Hartman, G., 2006, 'Shoah and intellectual witness', Reading on 1(1), 1-8.

Ilboudo, M., 2000, Murekatete, Le figuier/ Éditions de Fest'Africa, Bamako, Lille.

Kalisa, C., 2005, 'Le gos au Rwanda: Entretien avec Koulsy Lamko', in R.B. Gallimore \& C. Kalisa (eds.), Dix ans après: Réflexions sur le génocide rwandais, pp. 259-280, L'Harmattan, Paris.

Kalisa, C., 2006, 'Theatre and the Rwandan genocide', Peace Review: A Journal of Social Justice $18,515-521$.

Kayimahe, V., 2001, France-Rwanda: Les coulisses du genocide - Témoignage d'un rescapé, Dagorno, Paris.

LaCapra, D., 2001, Writing history, writing trauma, The John Hopkins University Press, Baltimore, MD.

Lamko, K., 2002, La phalène des collines, Le Serpent à Plumes, Paris.

Laub, D., 1995, 'Truth and testimony: The process and the struggle', in C. Caruth (ed.), Trauma: Explorations in memory, pp. 61-75, The John Hopkins University Press, Baltimore, MD.

Monénembo, T., 2000, L'aîné des orphelins, Éditions du Seuil, Paris.

Mphahlele, E., 2003a, 'African thought and belief', in E. Mphahlele et al. (eds.), Es'kia: Es'kia Mphahlele on education, African humanism and culture, social consciousness, literary appreciation, pp. 276-285, Kwela Books in association with Stainbank \& Associates, Cape Town.

Mphahlele, E., 2003b, 'Notes towards an introduction to African humanism: A personal enquiry - 1992', in E. Mphahlele et al. (eds.), Es'kia: Es'kia Mphahlele on education, African humanism and culture, social consciousness, literary appreciation, pp. 131-141, Kwela Books in association with Stainbank \& Associates, Cape Town

Mphahlele, E., 2003c, 'The fabric of African culture and religious beliefs - 1971', in E. Mphahlele et al. (eds.), Es'kia: Es'kia Mphahlele on education, African humanism and culture, social consciousness, literary appreciation, pp. 142-156, Kwela Books in association with Stainbank \& Associates, Cape Town.

Nayar, P.K., 2009, 'Affective travel: Terror and the human rights narrative in Véronique Tadjo's "The shadow of Imana"', Journal of English Studies 4(3/4), 35-49.

Norridge, Z., 2009, 'Bleeding scars from Rwanda: The interplay of text and image in Alain Kazinierakis and Yolande Mukagasana's Les Blessures du silence', French Cultural Studies 20(2), 133-148. http://dx.doi.org/10.1177/0957155809102629

Ricœur, P., 1983, Temps et récit: Tome l, Éditions du Seuil, Paris.

Ricœur, P., 1990, Time and narrative I, University of Chicago Press, Chicago, IL.

Ricœur, P. \& Antohi, S., 2005, 'Memory, history, forgiveness: A dialogue between Paul Ricœur and Sorin Antohi', Janus Head 8(1), 14-25.

Ricœur, P. \& Antohini, S., 2003, Mémoire, histoire, pardon: Un dialogue de Paul Ricœur avec Sorin Antohi, viewed 15 January 2012, from http://pasts.ceu.hu/node/1158

Small, A., 2007, 'The duty of memory: A solidarity of voices after the Rwandan genocide', Paragraph 30(1), 85-100. http://dx.doi.org/10.3366/prg.2007.0016

Tadjo, V., 2000, L'ombre d'Imana: Voyages jusqu'au bout du Rwanda, Actes Sud, Arles.

Tadjo, V., 2002, The shadow of Imana: Travels in the heart of Rwanda, transl. V. Wakerley, Heinemann, Johannesburg.

Tadjo, V., 2013, 'Lifting the cloak of (in)visibility: A writer's perspective', Research in African Literatures 44(2), 1-7. http://dx.doi.org/10.2979/reseafrilite.44.2.1

Waberi, A.A., 2004, Moisson de crânes: Textes pour le Rwanda, Le Serpent à Plumes, Monaco. 